Article

\title{
Antitumor Effects of Laminaria Extract Fucoxanthin on Lung Cancer
}

\author{
ChengHan Mei ${ }^{1}$, ShunChang Zhou ${ }^{2}$, Lin Zhu ${ }^{1}$, JiaXiong Ming ${ }^{1}$, FanDian Zeng ${ }^{1}$ \\ and Rong $\mathrm{Xu}{ }^{1, *}$ \\ 1 Department of Pharmacology, School of Basic Medicine, Tongji Medical College, Huazhong University of \\ Science and Technology, Wuhan 430030, China; ckklmch@sina.cn (C.M.); zhul_1024@sina.cn (L.Z.); \\ jxminghust@163.com (J.M.); fdzeng@163.com (F.Z.) \\ 2 Department of Laboratory Animal, Tongji Medical College, Huazhong University of Science and Technology, \\ Wuhan 430030, China; schzhou@sohu.com \\ * Correspondence: rongxu@hust.edu.cn; Tel./Fax: +86-27-8369-1785
}

Academic Editor: Paul Long

Received: 26 December 2016; Accepted: 28 January 2017; Published: 15 February 2017

\begin{abstract}
Lung cancer is the leading cause of cancer mortality worldwide and non-small-cell lung cancer (NSCLC) is the most common type. Marine plants provide rich resources for anticancer drug discovery. Fucoxanthin (FX), a Laminaria japonica extract, has attracted great research interest for its antitumor activities. Accumulating evidence suggests anti-proliferative effects of FX on many cancer cell lines including NSCLCs, but the detailed mechanisms remain unclear. In the present investigation, we confirmed molecular mechanisms and in vivo anti-lung cancer effect of FX at the first time. Flow cytometry, real-time PCR, western blotting and immunohistochemistry revealed that FX arrested cell cycle and induced apoptosis by modulating expression of p53, p21, Fas, PUMA, Bcl-2 and caspase-3/8. These results show that FX is a potent marine drug for human non-small-cell lung cancer treatment.
\end{abstract}

Keywords: fucoxanthin; non-small-cell lung cancer; cell cycle arrest; apoptosis

\section{Introduction}

Lung cancer is currently the most prevalent malignant tumor worldwide and has the fastest rising incidence and mortality rate of all cancers [1]. Lung cancers are classified into small cell lung carcinoma (SCLC) and non-small cell lung carcinoma (NSCLC). The latter accounts $85 \%$ of all cases. Most of NSCLC cases have reached locally advanced or metastatic stage at the time of diagnosis. Unlike SCLC, average five-year survival rate of NSCLC is only $10 \%-15 \%$ [2]. The well-established platinum-based regimen can only bring a five-year absolute benefit of 5.4\% [3]. Over the past 30 years, many potential therapeutic targets of lung cancer have been identified. Targeted therapy with epidermal growth factor receptor-tyrosine kinase inhibitors (EGFR-TKIs) have benefited many lung cancer patients, but they still suffer from drug resistance and compatibility [4,5]. To improve patients' survival and the quality of life, novel approaches to NSCLC are of special interest.

Numerous effective anticancer drugs have been discovered from natural sources, but an important untapped resource in edible seaweeds remains to be exploited. Among them, Laminaria japonica, a brown alga, has a long history of use in the diets of Asian cultures. It has also been used as anti-thyroid tumor, edema, tuberculosis and beriberi drugs in traditional Chinese medicine [6]. FX is an oxygenated carotenoid available from multiple species of edible seaweeds, e.g., Laminaria japonica, Undaria pinnatifida and Hijikia jusiformis [7]. It has shown to possess many biological activities such as suppression of pre-adipocyte differentiation [8], anti-mutagenicity [9], anti-ocular inflammation and anti-oxidation [10]. Moreover, accumulating evidence has shown that FX has anti-cancer cancer 
cell effects on several cancer cell lines, including lung, leukemia, cutaneous, colon, liver, prostate and breast cancer [11-17]. While the in vivo anti-tumor effects and underlying molecular mechanisms for its anticancer activity are still unclear, we isolated FX from Laminaria japonica and investigated its anti-cancer effects in NSCLC cells and in tumor-bearing nude mice.

\section{Results}

\subsection{FX Inhibits Proliferation in NSCLC Cells}

Human non-small cell lung cancer cells were treated with FX $(12.5-100 \mu \mathrm{M})$ for 24, 48, or $72 \mathrm{~h}$. Cell proliferations were significantly inhibited by FX (Figure 1). IC C $_{50}$ of NSCLC cells were presented in Table 1. The results demonstrated that FX exhibited a dose and time-dependent cytotoxicity effect on NSCLC cells.
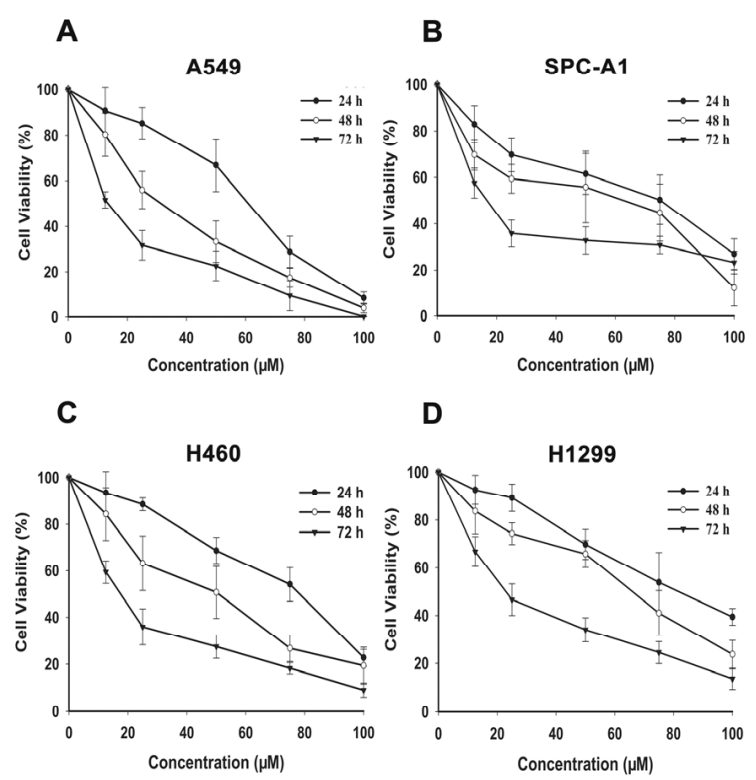

Figure 1. Effects of FX on proliferation of human NSCLC cells. Cytotoxicity of FX was assayed by CCK-8 method. A549 (A), SPC-A1 (B), H460 (C) and H1299 (D) cells were grown in a 96-well plate and exposed to various concentrations of $\operatorname{FX}(0,12.5,25,50,75$ and $100 \mu \mathrm{M})$ for 24,48 and $72 \mathrm{~h}$. Data are presented as means $\pm \mathrm{SD}(n=3)$.

Table 1. $\mathrm{IC}_{50}$ of fucoxanthin on proliferation of four NSCLC cell lines.

\begin{tabular}{ccc}
\hline Cells & Time (h) & IC $_{\mathbf{5 0}}(\boldsymbol{\mu M})$ \\
\hline \multirow{3}{*}{ A549 } & 24 & $51.6 \pm 3.89$ \\
& 48 & $28.8 \pm 1.99$ \\
& 72 & $14.32 \pm 0.21$ \\
\hline \multirow{3}{*}{ H460 } & 24 & $69.1 \pm 4.70$ \\
& 48 & $40.9 \pm 8.09$ \\
& 72 & $17.0 \pm 1.42$ \\
\hline \multirow{3}{*}{ SPC-A1 } & 24 & $60.1 \pm 2.39$ \\
& 48 & $38.8 \pm 2.08$ \\
& 72 & $15.0 \pm 5.25$ \\
\hline \multirow{3}{*}{ H1299 } & 24 & $81.5 \pm 4.72$ \\
& 48 & $56.4 \pm 1.54$ \\
\hline
\end{tabular}

Data are presented as means $\pm \mathrm{SD}(n=3)$. 


\subsection{FX Induces Cell Cycle Arrest in NSCLC Cells}

To determine the mechanisms by which FX inhibited NSCLC cells proliferation, we first investigated the effects of FX on cell cycle progression. A549 and H1299 cells were treated with FX $(12.5,25$ and $50 \mu \mathrm{M})$. After $48 \mathrm{~h}$, the cells were analyzed by flow cytometry. As shown in Figure 2A,B and Table 2, treatment with FX increased the percentage of cells in the $G_{0} / G_{1}$ phase of the cell cycle and reduced the percentage of cells in the $S$ phase. The $G_{0} / G_{1}$ arrest effect was concentration-dependent.
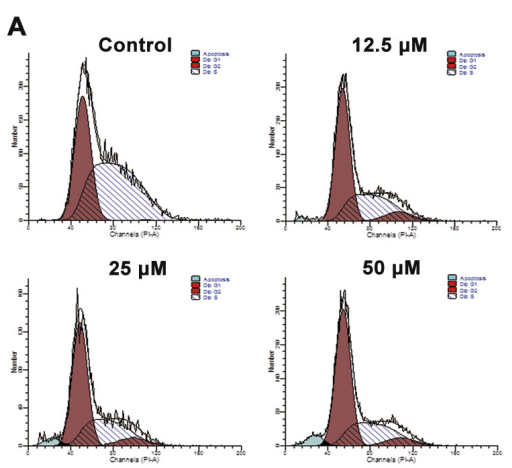

A549

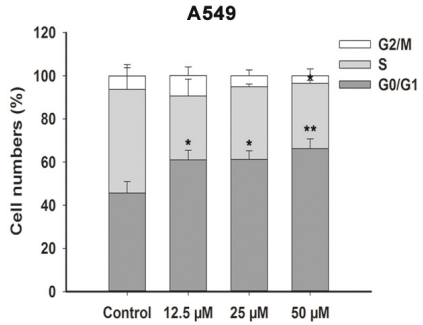

C

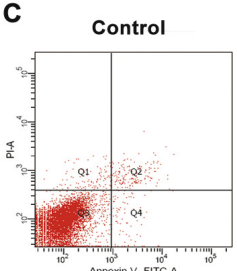

$25 \mu \mathrm{M}$
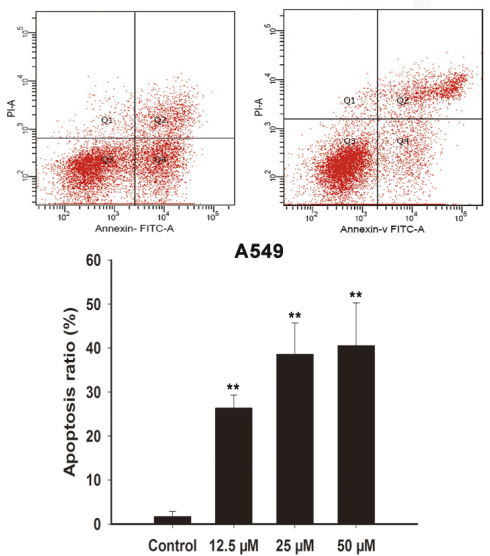
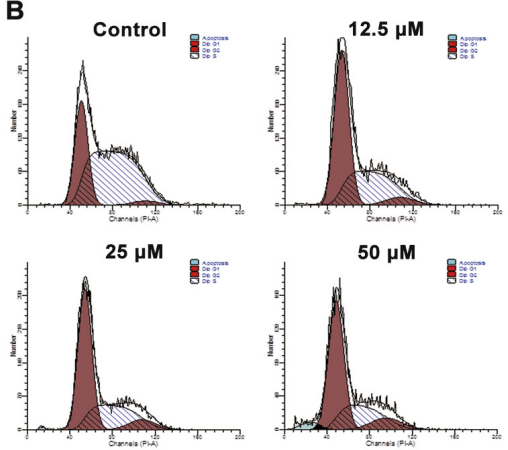

H1299

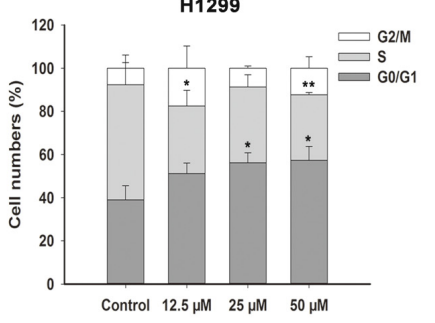

D
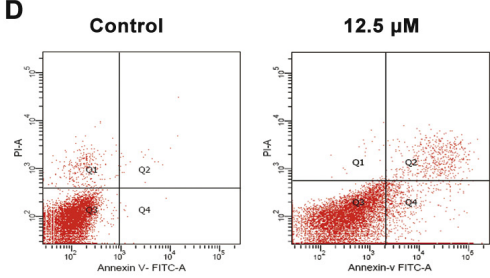

$25 \mu \mathrm{M}$

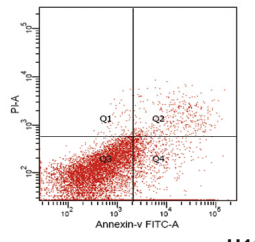

$50 \mu \mathrm{M}$
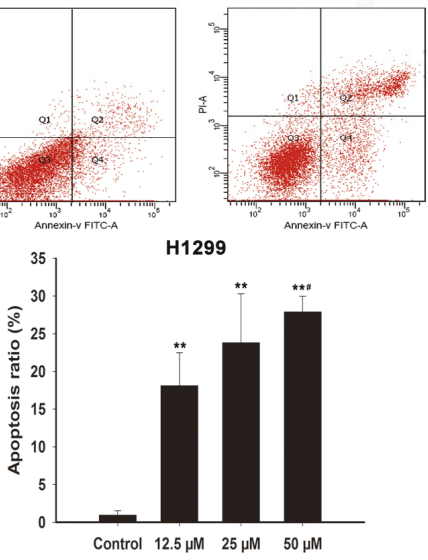

Figure 2. Induction of $\mathrm{G}_{0} / \mathrm{G}_{1}$ arrest and apoptosis by FX in A549 and H1299 cells. A549 (A) and H1299 (B) cells after the 48-h treatment of FX were stained with PI, then DNA content was analyzed by flow cytometry. $\mathrm{G}_{0} / \mathrm{G}_{1}, \mathrm{~S}$ and $\mathrm{G}_{2} / \mathrm{M}$ indicate different cell cycle phases. Annexin V-FITC/PI staining assay of A549 (C) and H1299 (D) cells was analyzed by flow cytometry to detect apoptosis after FX treatment for $48 \mathrm{~h}$ and Q4 represent cells in apoptotic stage. Data are presented as means $\pm \mathrm{SD}(n=3) .{ }^{*} p<0.05$, ** $p<0.01$ compared to the control group, ${ }^{*} p<0.05$, compared to the FX $12.5 \mu \mathrm{M}$ treatment group. 
Table 2. Cell cycle distribution of A549 and H1299 cells after fucoxanthin treatment for $48 \mathrm{~h}$.

\begin{tabular}{ccccccc}
\hline \multirow{2}{*}{ Group } & \multicolumn{3}{c}{ A549 Cells } & \multicolumn{3}{c}{ H1299 Cells } \\
\cline { 2 - 7 } & \multicolumn{3}{c}{ Cell Cycle Percentage (\%) } & \multicolumn{3}{c}{ Cell Cycle Percentage (\%) } \\
\cline { 2 - 7 } & $\mathbf{G}_{\mathbf{0}} / \mathbf{G}_{\mathbf{1}}$ & $\mathbf{S}$ & $\mathbf{G}_{\mathbf{2}} / \mathbf{M}$ & $\mathbf{G}_{\mathbf{0}} / \mathbf{G}_{\mathbf{1}}$ & $\mathbf{S}$ & $\mathbf{G}_{\mathbf{2}} / \mathbf{M}$ \\
\hline Control & $45.7 \pm 5.33$ & $48.0 \pm 10.1$ & $6.28 \pm 5.24$ & $39.0 \pm 6.51$ & $45.6 \pm 3.44$ & $7.69 \pm 6.16$ \\
FX 12.5 $\mu \mathrm{M}$ & $61.0 \pm 4.46^{*}$ & $29.7 \pm 7.82$ & $9.4 \pm 4.02$ & $51.3 \pm 4.85$ & $31.2 \pm 7.27^{*}$ & $17.5 \pm 10.3$ \\
FX $25 \mu \mathrm{M}$ & $61.3 \pm 3.95^{*}$ & $33.7 \pm 1.2$ & $5.01 \pm 2.76$ & $56.2 \pm 4.62^{*}$ & $35.1 \pm 5.63$ & $8.69 \pm 1.1$ \\
FX 50 $\mu \mathrm{M}$ & $66.3 \pm 4.55^{* *}$ & $30.2 \pm 1.41^{*}$ & $3.55 \pm 3.18$ & $57.3 \pm 6.42^{*}$ & $30.3 \pm 1.04^{* *}$ & $12.3 \pm 5.38$ \\
\hline
\end{tabular}

Data are presented as means $\pm \mathrm{SD}(n=3) .{ }^{*} p<0.05$ vs. the control group, ${ }^{* *} p<0.01$ vs. the control group.

\subsection{Effects of FX on the Expression of Cell Cycle Regulatory Proteins in NSCLC Cells}

To further study the molecular mechanism of $G_{0} / G_{1}$ phase cell cycle arrest induced by $F X$, we treated A549 and H1299 cells with FX $(12.5,25$ and $50 \mu \mathrm{M})$ for $48 \mathrm{~h}$. The expression of cell cycle-related proteins was examined by qRT-PCR and western blotting. As shown in Figure 3A,C, p21 ${ }^{\text {waf1/cip } 1}$ and p53 were upregulated in the A549 cell. H1299 cells lack p53, while its p21 ${ }^{\text {waf1/cip1 }}$ was upregulated (Figure 3B,D).
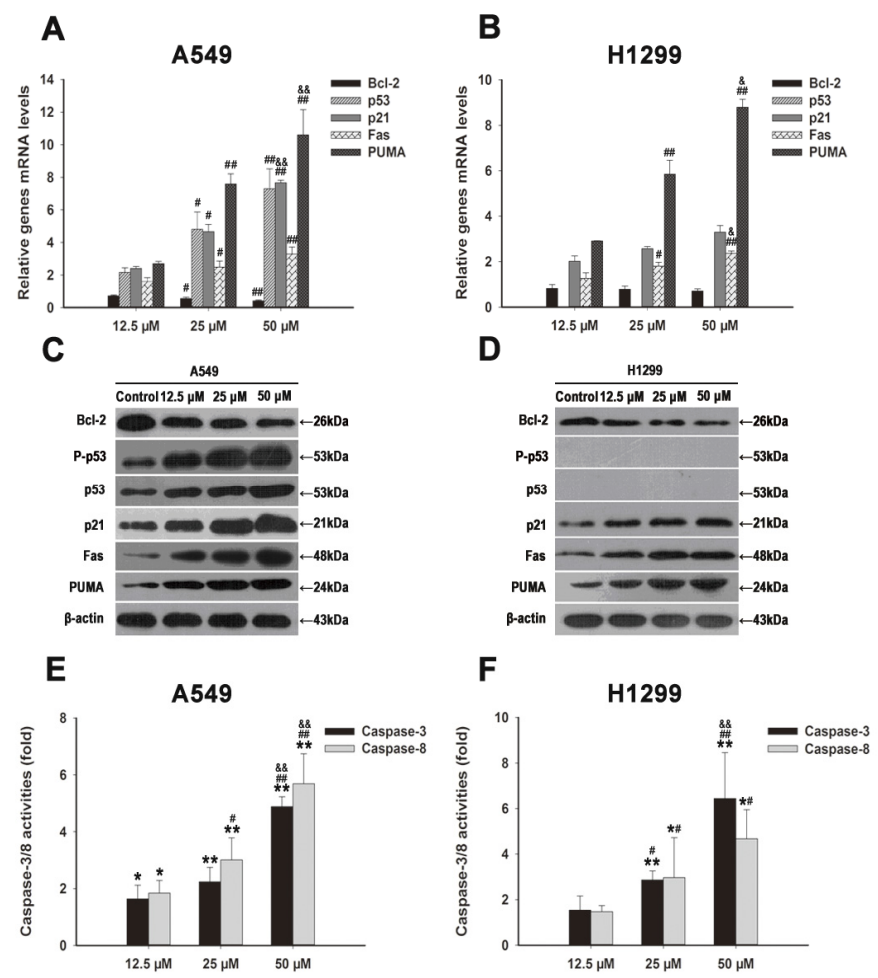

Figure 3. FX induced $G_{0} / G 1$ arrest and apoptosis through regulating p21 waf1/cip1, p53, Bcl-2, PUMA and Fas. Total cell RNA was extracted from A549 (A) and H1299 (B) cells after treating with FX $(0,12.5,25,50,75$ and $100 \mu \mathrm{M})$ for $48 \mathrm{~h}$. Corresponding mRNA levels of p53, p21 waf1/cip1, Bcl-2, PUMA and Fas genes were determined using qRT-PCR. Results were shown as the relative expression ratio of genes in A549 and $\mathrm{H} 1299$ cells, respectively. Western blot analysis of cell cycle arrest and apoptosis related proteins: p53, P-p53, PUMA, p21 waf1/cip1, Fas and Bcl-2, were performed after A549 (C) and H1299 (D) cells harvested after exposing to various concentrations of FX $(0,12.5,25$, $50 \mu \mathrm{M}$ ). Effects of FX on caspase-3/8 activities in A549 (E) and H1299 (F) cells were measured after $48 \mathrm{~h}$ of exposure similar to panel C/D by colorimetric method. When presented, means and standard deviations were obtained from three independent experiments. ${ }^{*} p<0.05,{ }^{* *} p<0.01$ compared to the control group; \# $p<0.05,{ }^{\# \#} p<0.01$ compared to the FX $12.5 \mu \mathrm{M}$ group; \& $p<0.05, \& \& p<0.01$ compared to the FX $25 \mu \mathrm{M}$ group. 


\subsection{FX Induces Apoptosis in NSCLC Cells}

We further investigated the apoptotic effects of FX in NSCLC cells. As shown in Figure 2C, the apoptosis rates in A549 cells were $26.4 \% \pm 2.96 \%, 38.6 \% \pm 7.13 \%$ and $40.6 \% \pm 9.72 \%$ in the $12.5,25$ and $50 \mu \mathrm{M}$ dose groups, which were much higher than the control group (1.70\% $\pm 1.13 \%)$. H1299's apoptosis rates were $18.1 \% \pm 4.38 \%, 23.8 \% \pm 6.51 \%$ and $27.9 \% \pm 2.07 \%(12.5,25$ and $50 \mu \mathrm{M})$ in the presence of FX, with control group only was $0.93 \% \pm 0.60 \%$ (Figure $2 \mathrm{D}$ ).

\subsection{Effects of FX on the Expression of Apoptosis-Related Genes in NSCLC Cells}

We examine mRNA and protein expression of some key apoptosis regulators after FX treatment in A549 and H1299 cells. They are Bcl-2, PUMA and Fas. As shown in Figure 3A,B, PUMA and Fas were upregulated while Bcl-2 was downregulated, in a dose-dependent manner. The activities of caspase- 3 and caspase- 8 were also analyzed. As shown in Figure 3E,F, the activity of caspase- 3 and caspase- 8 was increase after FX treatment in a dose dependent manner.

\subsection{FX Inhibits Human NSCLC A549 Tumor Xenograft Growth in Nude Mice}

The in vitro results demonstrate the potent anti-lung cancer activity by FX. Then, we evaluated the therapeutic efficacy of once daily oral administration of FX against human NSCLC cells A549 growing in nude mice. Five days after tumor cell inoculation, groups of mice $(n=8)$ received daily oral administrations of vehicle control or FX at doses of 5,15 , or $50 \mathrm{mg} / \mathrm{kg}$ body weight for five weeks. The weight of the solid tumors decreased significantly in FX treatment groups (Figure 4C). FX at 5, 15 and $50 \mathrm{mg} / \mathrm{kg}$ displayed potent antitumor effect with $62.0 \%, 69.9 \%$ and $78.1 \%$ tumor inhibition rates (Figure 4A), respectively. The greatest inhibition was found in mice receiving $50 \mathrm{mg} / \mathrm{kg} \mathrm{FX}(p<0.01)$. Importantly, by the endpoint in this study, no apparent toxic effects were observed in any of the FX treated animals. Mice body weights did not change much compared to the control group (Figure 4B) and no apparent morphological changes and metastatic nodules were observed in major organs.
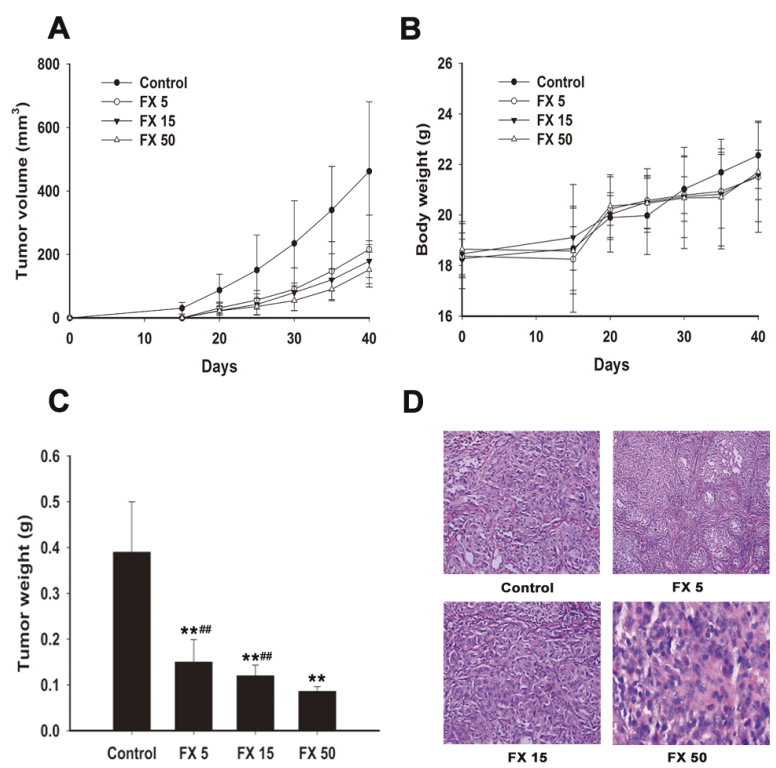

D

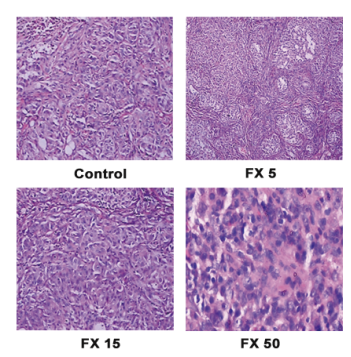

Figure 4. FX inhibits A549 tumor xenograft growth in vivo. The cells were subcutaneously injected into the left back of nude mice to induce tumor xenografts. Mice were gavaged with blank soybean oil, 5,15 and $50 \mathrm{mg} / \mathrm{kg}$ FX once daily for five weeks. Tumor volumes (A), bodyweights (B) and tumor weights $(\mathbf{C})$ were determined. Data are expressed as means $\pm \operatorname{SD}(n=8)$. ${ }^{* *}$ and ${ }^{\# \#}$ denote statistically significance $(p<0.01)$ compared to the control and FX $50 \mathrm{mg} / \mathrm{kg}$ groups, respectively. (D) Tumor morphology in the nude mice with xenografted A549 cells was examined by hematoxylin and eosin staining. Magnification: 400×. FX 5, FX 15 and FX 50 mean 5, 15, $50 \mathrm{mg} / \mathrm{kg}$ FX, respectively. 
Pathological analysis of tumor samples revealed that treatment with FX decreased tumor cell density and increased necrosis. The apoptotic morphological changes including cell contraction and nuclear pycnosis were observed (Figure 4D).

\subsection{FX Induces Apoptosis In Vivo}

To determine the mechanisms of anti-tumor effects of FX treatments, we examined tumor apoptosis. TUNEL staining results showed that FX promoted tumor cells apoptosis significantly (Figure 5A). As shown in Figure 5B,C, Bcl-2 was downregulated and caspase-3 was upregulated, both present a dose dependency $(p<0.01$ or $p<0.05)$. These results were consistent with the in vitro data, demonstrating that FX inhibited lung tumor by inducing tumor cell apoptosis.

A

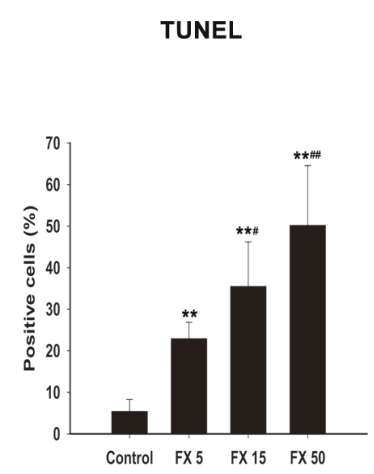

B

$\mathrm{Bcl}-2$

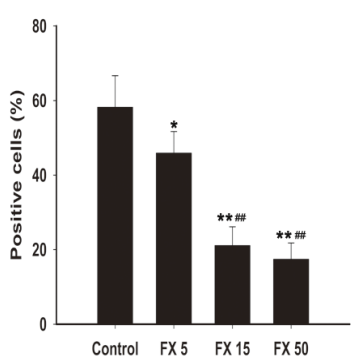

C

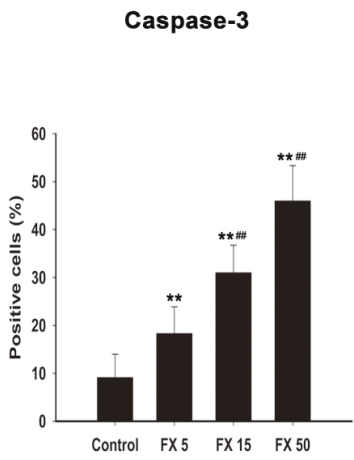

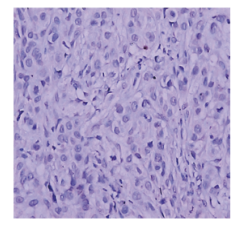

Control

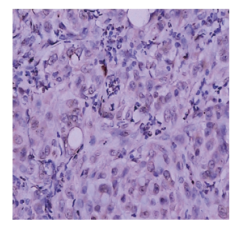

FX 15

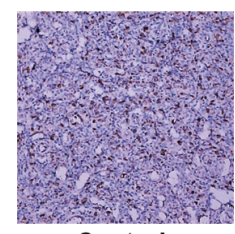

Control

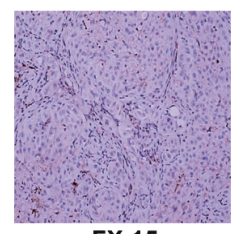

FX 15

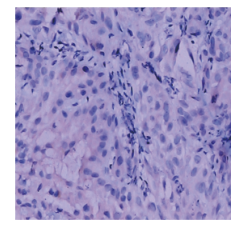

Control

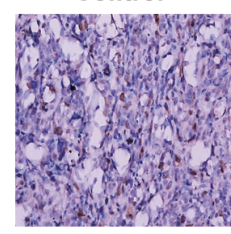

FX 15

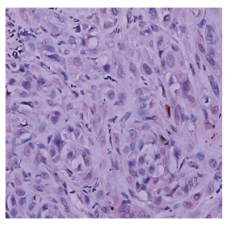

FX 5

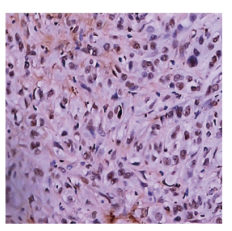

FX 50

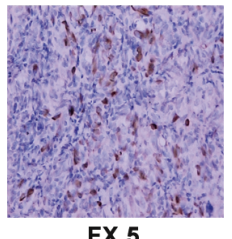

FX 5

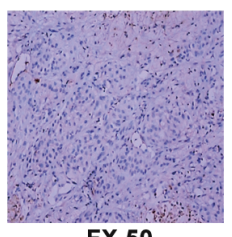

FX 50

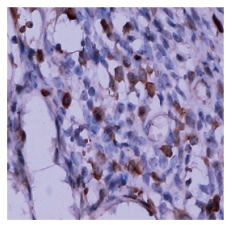

FX 5

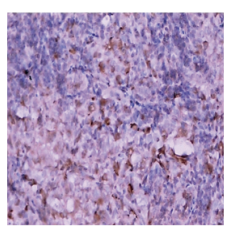

FX 50

Figure 5. Effects of FX on the protein expression of Bcl-2 and Caspase- 3 and apoptosis rates in A549 xenograft tumors. (A) TUNEL staining; Bcl-2 (B); and Caspase-3 (C) immunohistochemical staining. Magnification: 400×. FX 5, FX 15, FX 50 mean 5, 15 and $50 \mathrm{mg} / \mathrm{kg}$ FX respectively. Data are expressed as means $\pm \mathrm{SD}(n=5) .{ }^{*} p<0.05,{ }^{* *} p<0.01$ compared to the control group; ${ }^{\#} p<0.05,{ }^{\# \#} p<0.01$ compared to the FX $5 \mathrm{mg} / \mathrm{kg}$ group. 


\section{Discussion}

Fucoxanthin is a natural biologically active carotenoid abundant in micro- and macroalgae. FX has been shown to inhibit obesity $[18,19]$, inflammation $[20,21]$ and tumor growth $[11,12,22,23]$. However, its efficacy in NSCLC still remains to be further revealed. Here we uncovered that FX can significantly inhibit NSCLC growth and both in vitro and in vivo analyses have provided a detailed picture regarding the molecular mechanisms including cell cycle arrest and apoptosis induction.

Using cell viability assay, we demonstrated the anti-proliferative effect of FX and its doseand time- dependence in the NSCLC cell lines, including A549, SPC-A1, H460 and H1299, as shown in Figure 1. Our results are consistent with the previously reports that FX extracted from Undaria pinnatifida was effective in inhibiting the growth of A549 cells [24]. FX inhibited human colon carcinoma and HCT116 cells by cell cycle arrest during the $G_{0} / G_{1}$ phase [25]. Similarly, we found FX induced $\mathrm{G}_{0} / \mathrm{G}_{1}$ cycle arrest in A549 and $\mathrm{H} 1299$ cells significantly and dose dependently (Figure 2A,B). FX remarkably inhibited the viability of human colon cancer cell, cervical cancer and murine melanoma B16F10 cells by inducing apoptosis [26-28]. Using flow cytometry, we also observed that apoptosis ratios were increased after FX treatment in NSCLC cells (Figure 2C,D). Even in a low concentration, FX induced apoptosis remarkably, having shown that FX has therapeutic potential for NSCLC.

To further reveal the mechanisms of cell cycle arresting and pro-apoptotic effects after FX treatment, we performed qRT-PCR and western blotting assay. p21 waf1/cip1 being one of the downstream genes of $p 53$, functions as a regulator of cell cycle progression at $G_{1}$ and $S$ phases [29]. Consistent with previous reports $[25,30]$, we observed that $\mathrm{p} 21^{\text {waf1/cip } 1}$ was upregulated by FX both in mRNA and protein levels (Figure 3A-D). While FX has reported to increase the ratio of cells in $\mathrm{G}_{2} / \mathrm{M}$ phase in MGC-803 cells by regulating the JAK/STAT signaling pathway [31]. It is probable that FX interacts with different dominating pathways in different cell lines, thus might present different cell cycle behaviors. We concluded that $F X$ induced $G_{0} / G_{1}$ cycle arrest through up-regulating p21 waf1/cip1 in NSCLC cells.

Referring to apoptosis, death signaling requires clustering of Fas and finally the activation of caspase-8, which induces apoptosis [32,33]. Basically, we found Fas was upregulated significantly both in A549 and H1299 cells after the treatment of FX (Figure 3A-D). The mRNA and protein levels were changed similarly. We observed that p53 and P-p53 were upregulated with dose dependency after the treatment of FX in A549 cells (Figure 3A,C). p53 induces cell apoptosis through transcriptional-dependent and independent mechanisms by regulating genes, trans-activating the genes in both mitochondrial and death receptor pathways as well as trans repressing IGFR and Bcl-2 [34]. What's more, PUMA is involved in apoptosis and can be induced by a variety of signals $[35,36]$. After activation, PUMA interacts with anti-apoptotic $\mathrm{Bcl}-2$, thus regulate apoptosis by controlling mitochondrial permeability [35,37]. As shown in Figure 3A-D, PUMA was upregulated and Bcl-2 was downregulated with dose dependency (Figure 3A-D). Biochemically, caspase cascade activation and DNA fragmentation play a key role in apoptosis $[38,39]$. We found that FX could increase caspase-3 and caspase- 8 activity remarkably (Figure 3E,F). Fas is an extrinsic factor of apoptosis while Bcl-2 and PUMA are intrinsic factors and caspase-8 plays an important role in extrinsic apoptosis [40]. Thus, we concluded that FX was able to induce apoptosis through endogenous and exogenous pathway of apoptosis in NSCLC cells and these effects were dose dependent.

After confirming the anti- proliferative and pro-apoptosis effects of FX in NSCLC cells in vitro, we wondered if FX has the above effects in vivo, too. So A549 xenograft induction was performed in nude mice. It has been illustrated that FX suppressed the growth of HeLa cells in vivo [27] and inhibited the growth of sarcoma 180 (S180) in mice significantly [41]. Similarly, FX significantly decreased the tumor volume (Figure 4A) and weight (Figure 4C) with a dose dependent behavior. We did not observe obvious body weight loss (Figure 4B) and morphological changes in major organs after FX treatment. It demonstrated that FX had a lower toxicity than traditional chemotherapy drugs. Then we performed HE staining. As shown in Figure 4D, FX caused morphological changes of necrosis and apoptosis. Furthermore, we used TUNEL staining and revealed that FX could increase 
apoptosis ratio remarkably with a dose dependent behavior in vivo (Figure 5A). To further reveal the pro-apoptosis mechanism, we performed immunohistochemistry analysis to detect the protein level changes of Bcl-2 and caspase-3 in tumor tissues. Consistent with previous results in vitro (Figure 3), FX dose dependently decreased Bcl-2 and increased caspase-3 (Figure 5B,C) level. Thus, we concluded that FX induced apoptosis remarkably in vivo through upregulating caspase-3 and inhibiting Bcl-2.

In summary, our study has elucidated the anti-cancer mechanisms of FX in NSCLC cells for inducing cell cycle arrest and apoptosis. In addition, we also found that FX could inhibit A549 tumor growth in nude mice. Biopsy analysis has also verified the apoptosis induction mechanism. In the future, attention should be given to establishing a more detailed understanding of the mechanisms and the synergistic antitumor effects of combined FX and other drugs. In conclusion, our study provided convincible data to merit application of FX in NSCLC drug discovery.

\section{Experimental Section}

\subsection{Reagents and Chemicals}

FX was isolated from Laminaria japonica, as previously described [42]. Purification from the extract was followed the method of Yan et al. [43]. The purity of FX was 100\%, detected by HPLC and HPTLC, respectively. It was provided by HYDROX Co., Ltd. (Saitama, Japan) and Rongbao HighTech Co., Ltd. (Wuhan, China). The followings were purchased from Sigma (St. Louis, MO, USA): propidium iodide (PI), trypsin. Annexin V-FITC Apoptosis Detection Kits were purchased from Key Gen Biotech (Nanjing, Jiang Su, China). RNA-direct ${ }^{\mathrm{TM}}$ SYBR Green Real time PCR Master Mix kits were purchased from Toyobo Co. (Osaka, Japan). Caspase-3 and caspase-8 assay kits were purchased from BD Biosciences (San Diego, CA, USA). Cell counting kit-8 kits were purchased from Dojindo Laboratories (Kumamoto, Japan). Anti-p53 and anti-phosphated p53 antibodies were purchased from Cell Signaling Technology (Danvers, MA, USA). Anti-Bcl-2, anti-p21 waf1/cip1, anti-PUMA, anti-FAS, anti- $\beta$-actin antibodies and horseradish peroxidase-conjugated secondary antibodies were from Santa Cruz Biotechnology, Inc. (Santa Cruz, CA, USA). Polyclonal Antibodies against p53, Bcl-2, Caspase-3 were from Boster Biological Technology, Ltd. (Wuhan, Hubei, China). ECL was purchased from Pierce Biotechnology (Waltham, MA, USA). Tunnel staining in situ cell death detection kit was purchased from Roche (Minneapolis, MN, USA). Immunohistochemistry kits for rabbit and mouse antibodies were purchased from Gene Tech (Shanghai, China).

\subsection{Cell Culture}

All NSCLC cell lines (A549, H460, SPC-A1 and H1299) were obtained from Cell Bank of the Chinese Academy of Sciences Committee Type Culture Collection (Shanghai, China) and cultured in RPMI-1640 medium (Gibico, Grand Island, NY, USA) with 10\% fetal bovine serum, $100 \mathrm{U} / \mathrm{mL}$ penicillin and $100 \mathrm{pg} / \mathrm{mL}$ streptomycin (Gibico, Grand Island, NY, USA) in a $5 \% \mathrm{CO}_{2}$ and $95 \%$ air incubator at $37^{\circ} \mathrm{C}$. The cells were passaged by $0.125 \%$ trypsin-EDTA when they reached $80 \%$ confluence.

\subsection{Cell Viability}

Cells were treated with different concentrations of FX for 24,48 , or $72 \mathrm{~h}$ before cytotoxic activity was evaluated by the Cell counting kit- 8 (Dojindo Laboratories, Kumamoto, Japan) and the absorbance was measured at $450 \mathrm{~nm}$.

\subsection{Cell Cycle Analysis}

Cells $\left(5 \times 10^{5}\right.$ /well) were seeded into 6-well plates and exposed to FX at various concentrations $(12.5,25$ and $50 \mu \mathrm{M})$ for $48 \mathrm{~h}$ and then harvested and washed with PBS, fixed in $70 \%$ ethanol at $4{ }^{\circ} \mathrm{C}$. Staining went along with PBS containing $1 \mathrm{mg} / \mathrm{mL}$ RNaseA and $50 \mu \mathrm{g} / \mathrm{mL}$ PI in the dark at room temperature for $20 \mathrm{~min}$. The cell cycle was measured using FACSCalibur ${ }^{\circledR}$ flow cytometer (BD, Franklin Lakes, NJ, USA). 


\subsection{Measurement of Apoptosis by Annexin V-FITC/PI Staining}

Flow cytometry was used to quantitatively detect the apoptotic rate. Cells $\left(5 \times 10^{5} / \mathrm{mL}\right)$ were seeded into 6-well plates and exposed to FX at various concentrations (12.5, 25 and $50 \mu \mathrm{M})$ for $48 \mathrm{~h}$ and then harvested and washed with phosphate buffered saline (PBS). Staining went along with bonding buffer containing Annexin V-FITC in the dark at room temperature for $10 \mathrm{~min}$ and then added PI in the dark $4{ }^{\circ} \mathrm{C}$ for $10 \mathrm{~min}$. The apoptotic cells were analyzed with FACS Calibur ${ }^{\mathrm{TM}}$ flow cytometer.

\subsection{Real-Time Quantitative PCR}

After $48 \mathrm{~h}$ treatment of FX at the concentration of $12.5,25$ and $50 \mu \mathrm{M}$, total RNA was isolated with Trizol reagent (Invitrogen, Grand Island, NY, USA) following the manufacturer's instructions. The RNA samples were reverse-transcribed using RNA-direct ${ }^{\mathrm{TM}}$ SYBR Green Realtime PCR Master Mix kit (Toyobo, Osaka, Japan). RNA amplification and quantitative determination were carried out in a SLAN-96P real-time PCR system (Hongshi Medical Technology Company, Ltd., Shanghai, China). Cycling conditions were performed as follows: $1 \mathrm{~min}$ at $50{ }^{\circ} \mathrm{C}, 2 \mathrm{~min}$ at $94^{\circ} \mathrm{C}$, then 40 cycles of $15 \mathrm{~s}$ at $94{ }^{\circ} \mathrm{C}, 15 \mathrm{~s}$ annealing, $45 \mathrm{~s}$ at $72{ }^{\circ} \mathrm{C}$ and then $10 \mathrm{~min}$ at $72{ }^{\circ} \mathrm{C}$. $\beta$-actin mRNA levels were also quantified in each sample and were used as a normalization control. The comparative $\mathrm{C}_{\mathrm{T}}$ method was used to analyze the PCR data.

\subsection{Western Blot}

Cells were lysed with ice-cold lysis buffer (50 mM Tris- $\mathrm{HCl}$, pH 7.4, $100 \mathrm{mM} \mathrm{NaCl}, 1 \mathrm{mM}$ EDTA, $20 \mathrm{mM} \mathrm{NaF}, 3 \mathrm{mM} \mathrm{Na} \mathrm{VO}_{4}, 1 \mathrm{mM}$ PMSF) for $30 \mathrm{~min}$ on ice. Cell lysates were then collected after centrifugation at 12,000 rpm for $5 \mathrm{~min}$ at $4{ }^{\circ} \mathrm{C}$. Equal amount of sample proteins were separated on $10 \%$ SDS-PAGE gels and transferred onto PVDF membranes (Millipore, Billerica, MA, USA). After blocking with $5 \%$ defatted milk powder in TBST buffer $(10 \mathrm{mM}$ Tris, $\mathrm{pH} 7.5,150 \mathrm{mM} \mathrm{NaCl}$ and $0.05 \%$ Tween 20 ) for $45 \mathrm{~min}$ at room temperature. The protein samples were then immunoblotted with primary monoclonal antibodies. They were mouse monoclonal antibody against phosphate-p53; rabbit polyclonal antibodies against p53, Bcl-2, Fas, p21 ${ }^{\text {waf1/cip1 }}$ and $\beta$-actin; and goat polyclonal antibodies against PUMA. After incubating for $1 \mathrm{~h}$ at room temperature with secondary antibodies (horseradish peroxidase-conjugated goat anti-mouse IgG, goat anti-rabbit IgG and rabbit anti-goat $\operatorname{IgG}$ ), antigens were visualized using enhanced chemiluminescence using ECL according to the manufacturer's instructions.

\subsection{Caspase-3 and Caspase-8 Activity Assay}

Enzymatic activities of caspase- 3 and -8 were measured using caspase-3, caspase- 8 colorimetric assay kits, according to the manufacturer's procedure. After exposure to 12.5, 25 and $50 \mu \mathrm{M}$ FX for $48 \mathrm{~h}$, control or treated cells were lysed in $50 \mu \mathrm{L}$ chilled cell lysis buffer. Supernatant was collected by centrifugation at $11,500 \mathrm{rpm}$ for $10 \mathrm{~min}$ at $4{ }^{\circ} \mathrm{C} .50 \mu \mathrm{L}$ of $2 \times$ Reaction Buffer/DTT Mix was added and $1 \mu \mathrm{L}$ of caspase-3 inhibitor (DEVD-fmk) or caspase-8 inhibitor (IETD-fmk) was incubated with $50 \mu \mathrm{L}$ of supernatant from a sample on ice for $30 \mathrm{~min} .5 \mu \mathrm{L}$ of $1 \mathrm{mM}$ capase- 3 or caspase- 8 substrate (DEVD-pNA) was added and incubated at $37^{\circ} \mathrm{C}$ for $1 \mathrm{~h}$ in a water bath. The samples were analyzed at $405 \mathrm{~nm}$ in a microplate reader (Awareness Technology Inc., Palm City, FL, USA). The activities of caspase- 3 and caspase- 8 were calculated according to the calculated formula in the assay kit.

\subsection{Antitumor Activity Study of FX In Vivo}

Animal experiments were approved by the Institutional Animal Ethical Committee of Huazhong University of Science and Technology. Female and male (1:1 ratio) BALB/c nude mice (18-20 g; 6-8 weeks of age) were purchased from the Vital River Laboratories (Beijing, China) and received care in compliance with the guidelines proposed by Institutional Animal Care and Use Committee. All the mice were injected in the right flank subcutaneously with A549 cells $\left(2 \times 10^{6}\right.$ per mouse). 
After five days, tumor-bearing mice were randomly divided into four groups $(n=8$, female: male $=1: 1$ ). The vehicle control group was gavaged with blank soybean oil. In the FX treatment groups, FX was administered at a dose of 5,15 and $50 \mathrm{mg} / \mathrm{kg}$ each day orally for five weeks. All groups were observed for 40 days. Mice were weighed and tumors were measured using calipers every five days. Tumor volumes were determined by measuring the length $(L)$ and the width $(W)$ and calculated as $V=\pi / 6 \times L \times W^{2}$. The animals were sacrificed on Day 41 when subcutaneous tumors were isolated and weighed to calculate the tumor inhibition rate. Tumor inhibition rate $(\%)=(1-$ tumor tissue weight of treatment group /tumor tissue weight of control group $)$ $\times 100 \%$. Tumor tissues were fixed in $10 \%$ neutral formaldehyde solution, embedded in paraffin and sliced into $4-5 \mu \mathrm{m}$ sections for hematoxylin/eosin, immunohistochemical staining and TUNEL detection, the other parts are stored frozen $\left(-80^{\circ} \mathrm{C}\right)$.

\subsection{Immunohistochemistry Analysis}

The immunohistochemical staining of tumor Bcl-2 and Caspase-3 expression followed the manufacturer's instructions. The images were captured under a CX21 microscope (Olympus, Shinjuku, Tokyo, Japan).

\subsection{TUNEL}

To detect apoptotic cells in tumor tissues, the TUNEL assay was performed following the manufacturer's protocol. Cell nuclei with brown staining were defined as TUNEL-positive nuclei. To quantify TUNEL-positive cells, the number of positive cells was counted in five random areas at $400 \times$ magnifications.

\subsection{Statistics}

Data were expressed as means \pm S.D. from at least three independent experiments. Statistical analysis was performed using SPSS 19. $p$ Values were calculated using Student's $t$ test (alpha level: 0.05 , two-tailed). The differences between the groups were considered significant at $p$ values less than 0.05 .

\section{Conclusions}

Fucoxanthin inhibited NSCLC cell growth both in vitro and in vivo. FX induced cell cycle arrest and apoptosis by upregulating p53, p21 waf1/cip1, PUMA and Fas and downregulating Bcl-2. Our results provide the possibility that FX will become a potential drug for patients with NSCLC.

Acknowledgments: This study was supported by the National Natural Science Foundation of China (Nos. 81301314 and 81672947), Young Scholar Foundation of Health and Family Planning Commission of Hubei Province (WJ2015Q010) and The Fundamental Research Funds for the Central Universities, HUST (2016YXZD035).

Author Contributions: All the authors contributed sufficiently for their participation in the study, as justified below: Rong $\mathrm{Xu}$ conceived and designed the research. FanDian Zeng supervised the research. Rong Xu, ChengHan Mei, ShunChang Zhou, Lin Zhu and JiaXiong Ming performed the experiments. Rong Xu and ChengHan Mei analyzed the data and wrote the paper. Rong Xu reviewed and edited the paper.

Conflicts of Interest: The authors declare no conflict of interest.

\section{References}

1. Chen, W.; Zheng, R.; Baade, P.D.; Zhang, S.; Zeng, H.; Bray, F.; Jemal, A.; Yu, X.Q.; He, J. Cancer statistics in china, 2015. CA Cancer J. Clin. 2016, 66, 115-132. [CrossRef] [PubMed]

2. Chang, G.-C.; Chen, K.-C.; Yang, T.-Y.; Yin, M.-C.; Lin, C.-P.; Kuo, B.I.-T.; Hsu, J.-Y. Activity of gefitinib in advanced non-small-cell lung cancer with very poor performance status. Investig. New Drugs 2005, 23, 73-77. [CrossRef] [PubMed] 
3. Pignon, J.-P.; Tribodet, H.; Scagliotti, G.V.; Douillard, J.-Y.; Shepherd, F.A.; Stephens, R.J.; Dunant, A.; Torri, V.; Rosell, R.; Seymour, L. Lung adjuvant cisplatin evaluation: A pooled analysis by the lace collaborative group. J. Clin. Oncol. 2008, 26, 3552-3559. [CrossRef] [PubMed]

4. De Mello, R.A.; Veloso, A.F.; Catarina, P.E.; Nadine, S.; Antoniou, G. Potential role of immunotherapy in advanced non-small-cell lung cancer. Oncol. Targets Ther. 2017, 10, 21-30. [CrossRef] [PubMed]

5. Dholaria, B.; Hammond, W.; Shreders, A.; Lou, Y. Emerging therapeutic agents for lung cancer. J. Hematol. Oncol. 2016, 9, 138. [CrossRef] [PubMed]

6. Liu, Y.; Wang, Z.; Zhang, J. Dietary Chinese Herbs: Chemistry, Pharmacology and Clinical Evidence; Springer Science \& Business Media: Berlin, Germany, 2015; pp. 767-780.

7. D'Orazio, N.; Gemello, E.; Gammone, M.A.; de Girolamo, M.; Ficoneri, C.; Riccioni, G. Fucoxantin: A treasure from the sea. Mar. Drugs 2012, 10, 604-616. [CrossRef] [PubMed]

8. Maeda, H.; Hosokawa, M.; Sashima, T.; Takahashi, N.; Kawada, T.; Miyashita, K. Fucoxanthin and its metabolite, fucoxanthinol, suppress adipocyte differentiation in 3T3-L1 cells. Int. J. Mol. Med. 2006, 18, 147-152. [CrossRef] [PubMed]

9. Nishino, H. Cancer prevention by carotenoids. Mutat. Res. 1998, 402, 159-163. [CrossRef]

10. Sachindra, N.M.; Sato, E.; Maeda, H.; Hosokawa, M.; Niwano, Y.; Kohno, M.; Miyashita, K. Radical scavenging and singlet oxygen quenching activity of marine carotenoid fucoxanthin and its metabolites. J. Agric. Food Chem. 2007, 55, 8516-8522. [CrossRef] [PubMed]

11. Kumar, S.R.; Hosokawa, M.; Miyashita, K. Fucoxanthin: A marine carotenoid exerting anti-cancer effects by affecting multiple mechanisms. Mar. Drugs 2013, 11, 5130-5147. [CrossRef] [PubMed]

12. Peng, J.; Yuan, J.-P.; Wu, C.-F.; Wang, J.-H. Fucoxanthin, a marine carotenoid present in brown seaweeds and diatoms: Metabolism and bioactivities relevant to human health. Mar. Drugs 2011, 9, 1806-1828. [CrossRef] [PubMed]

13. Rengarajan, T.; Rajendran, P.; Nandakumar, N.; Balasubramanian, M.P.; Nishigaki, I. Cancer preventive efficacy of marine carotenoid fucoxanthin: Cell cycle arrest and apoptosis. Nutrients 2013, 5, 4978-4989. [CrossRef] [PubMed]

14. Kim, K.-N.; Heo, S.-J.; Kang, S.-M.; Ahn, G.; Jeon, Y.-J. Fucoxanthin induces apoptosis in human leukemia HL-60 cells through a ROS-mediated Bcl-xL pathway. Toxicol. In Vitro 2010, 24, 1648-1654. [CrossRef] [PubMed]

15. Takahashi, K.; Hosokawa, M.; Kasajima, H.; Hatanaka, K.; Kudo, K.; Shimoyama, N.; Miyashita, K. Anticancer effects of fucoxanthin and fucoxanthinol on colorectal cancer cell lines and colorectal cancer tissues. Oncol. Lett. 2015, 10, 1463-1467. [CrossRef] [PubMed]

16. Satomi, Y. Fucoxanthin induces GADD45A expression and G1arrest with SAPK/JNK activation in LNCap human prostate cancer cells. Anticancer Res. 2012, 32, 807-813. [PubMed]

17. Rwigemera, A.; Mamelona, J.; Martin, L.J. Comparative effects between fucoxanthinol and its precursor fucoxanthin on viability and apoptosis of breast cancer cell lines MCF-7 and MDA-MB-231. Anticancer Res. 2015, 35, 207-219. [PubMed]

18. Maeda, H.; Hosokawa, M.; Sashima, T.; Funayama, K.; Miyashita, K. Fucoxanthin from edible seaweed, Undaria pinnatifida, shows antiobesity effect through UCP1 expression in white adipose tissues. Biochem. Biophys. Res. Commun. 2005, 332, 392-397. [CrossRef] [PubMed]

19. Gammone, M.A.; D'Orazio, N. Anti-obesity activity of the marine carotenoid fucoxanthin. Mar. Drugs 2015, 13, 2196-2214. [CrossRef] [PubMed]

20. Kim, K.-N.; Heo, S.-J.; Yoon, W.-J.; Kang, S.-M.; Ahn, G.; Yi, T.-H.; Jeon, Y.-J. Fucoxanthin inhibits the inflammatory response by suppressing the activation of NF- $\mathrm{KB}$ and MAPKs in lipopolysaccharide-induced RAW 264.7 macrophages. Eur. J. Pharmacol. 2010, 649, 369-375. [CrossRef] [PubMed]

21. Hwang, P.-A.; Phan, N.N.; Lu, W.-J.; Hieu, B.T.N.; Lin, Y.-C. Low-molecular-weight fucoidan and high-stability fucoxanthin from brown seaweed exert prebiotics and anti-inflammatory activities in Caco-2 cells. Food Nutr. Res. 2016, 60, 32033. [CrossRef] [PubMed]

22. Liu, Y.; Zheng, J.; Zhang, Y.; Wang, Z.; Yang, Y.; Bai, M.; Dai, Y. Fucoxanthin activates apoptosis via inhibition of PI3K/Akt/mTOR pathway and suppresses invasion and migration by restriction of p38-MMP-2/9 pathway in human glioblastoma cells. Neurochem. Res. 2016, 41, 2728-2751. [CrossRef] [PubMed]

23. Martin, L.J. Fucoxanthin and its metabolite fucoxanthinol in cancer prevention and treatment. Mar. Drugs 2015, 13, 4784-4798. [CrossRef] [PubMed] 
24. Wang, S.K.; Li, Y.; White, W.L.; Lu, J. Extracts from New Zealand Undaria pinnatifida containing fucoxanthin as potential functional biomaterials against cancer in vitro. J. Funct. Biomater. 2014, 5, 29-42. [CrossRef] [PubMed]

25. Das, S.K.; Hashimoto, T.; Shimizu, K.; Yoshida, T.; Sakai, T.; Sowa, Y.; Komoto, A.; Kanazawa, K. Fucoxanthin induces cell cycle arrest at g G0/G1 phase in human colon carcinoma cells through up-regulation of p21WAF1/Cip1. Biochim. Biophys. Acta 2005, 1726, 328-335. [CrossRef] [PubMed]

26. Hosokawa, M.; Kudo, M.; Maeda, H.; Kohno, H.; Tanaka, T.; Miyashita, K. Fucoxanthin induces apoptosis and enhances the antiproliferative effect of the PPARgamma ligand, troglitazone, on colon cancer cells. Biochim. Biophys. Acta 2004, 1675, 113-119. [CrossRef] [PubMed]

27. Ye, G.; Lu, Q.; Zhao, W.; Du, D.; Jin, L.; Liu, Y. Fucoxanthin induces apoptosis in human cervical cancer cell line HeLa via PI3K/Akt pathway. Tumour Biol. 2014, 35, 11261-11267. [CrossRef] [PubMed]

28. Kim, K.-N.; Ahn, G.; Heo, S.-J.; Kang, S.-M.; Kang, M.-C.; Yang, H.-M.; Kim, D.; Roh, S.W.; Kim, S.-K.; Jeon, B.-T. Inhibition of tumor growth in vitro and in vivo by fucoxanthin against melanoma B16F10 cells. Environ. Toxicol. Pharmacol. 2013, 35, 39-46. [CrossRef] [PubMed]

29. Gartel, A.L.; Radhakrishnan, S.K. Lost in transcription: P21 repression, mechanisms, and consequences. Cancer Res. 2005, 65, 3980-3985. [CrossRef] [PubMed]

30. Wang, L.; Zeng, Y.; Liu, Y.; Hu, X.; Li, S.; Wang, Y.; Li, L.; Lei, Z.; Zhang, Z. Fucoxanthin induces growth arrest and apoptosis in human bladder cancer T24 cells by up-regulation of p21 and down-regulation of mortalin. Acta Biochim. Biophys. Sin. 2014, 46, 877-884. [CrossRef] [PubMed]

31. Yu, R.-X.; Hu, X.-M.; Xu, S.-Q.; Jiang, Z.-J.; Yang, W. Effects of fucoxanthin on proliferation and apoptosis in human gastric adenocarcinoma MGC-803 cells via JAK/STAT signal pathway. Eur. J. Pharmacol. 2011, 657, 10-19. [CrossRef]

32. Cappello, F.; Bellafiore, M.; Palma, A.; Bucchieri, F. Defective apoptosis and tumorigenesis: Role of p53 mutation and Fas/FasL system dysregulation. Eur. J. Histochem. 2002, 46, 199-208. [CrossRef] [PubMed]

33. Li, H.; Zhu, H.; Xu, C.-J.; Yuan, J. Cleavage of BID by caspase 8 mediates the mitochondrial damage in the Fas pathway of apoptosis. Cell 1998, 94, 491-501. [CrossRef]

34. Sun, Y. P53 and its downstream proteins as molecular targets of cancer. Mol. Carcinog. 2006, 45, 409-415. [CrossRef] [PubMed]

35. Yu, J.; Zhang, L. PUMA, a potent killer with or without p53. Oncogene 2008, 27, S71-S83. [CrossRef] [PubMed]

36. Nakano, K.; Vousden, K.H. PUMA, a novel proapoptotic gene, is induced by p53. Mol. Cell 2001, 7, 683-694. [CrossRef]

37. Katsumata, K.; Sumi, T.; Tomioka, H.; Aoki, T.; Koyanagi, Y. Induction of apoptosis by p53, bax, bcl-2, and p21 expressed in colorectal cancer. Int. J. Clin. Oncol. 2003, 8, 352-356. [CrossRef] [PubMed]

38. Salvesen, G.S. Caspases: Opening the boxes and interpreting the arrows. Cell Death Differ. 2002, 9, 3-5. [CrossRef] [PubMed]

39. Ghavami, S.; Hashemi, M.; Ande, S.R.; Yeganeh, B.; Xiao, W.; Eshraghi, M.; Bus, C.J.; Kadkhoda, K.; Wiechec, E.; Halayko, A.J. Apoptosis and cancer: Mutations within caspase genes. J. Med. Genet. 2009, 46, 497-510. [CrossRef] [PubMed]

40. McIlwain, D.R.; Berger, T.; Mak, T.W. Caspase functions in cell death and disease. Cold Spring Harb. Perspect. Biol. 2013, 5, a008656. [CrossRef] [PubMed]

41. Wang, J.; Chen, S.; Xu, S.; Yu, X.; Ma, D.; Hu, X.; Cao, X. In vivo induction of apoptosis by fucoxanthin, a marine carotenoid, associated with down-regulating STAT3/EGFR signaling in sarcoma 180 (S180) xenografts-bearing mice. Mar. Drugs 2012, 10, 2055-2068. [CrossRef] [PubMed]

42. Hosokawa, M.; Wanezaki, S.; Miyauchi, K.; Kurihara, H.; Kohno, H.; Kawabata, J.; Odashima, S.; Takahashi, K. Apoptosis-inducing effect of fucoxanthin on human leukemia cell line HL-60. Food Sci. Technol. Res. 1999, 5, 243-246. [CrossRef]

43. Yan, X.; Chuda, Y.; Suzuki, M.; Nagata, T. Fucoxanthin as the major antioxidant in Hijikia fusiformis, a common edible seaweed. Biosci. Biotechnol. Biochem. 1999, 63, 605-607. [CrossRef] [PubMed]

(C) 2017 by the authors; licensee MDPI, Basel, Switzerland. This article is an open access article distributed under the terms and conditions of the Creative Commons Attribution (CC BY) license (http:/ / creativecommons.org/licenses/by/4.0/). 